\title{
THE RELATION OF INFLUENZA VIRUS AND BACTERIA IN THE ETIOLOGY OF PNEUMONIA ${ }^{1,2}$
}

\author{
By ELIZABETH STARBUCK MAXWELL, THOMAS G. WARD, AND \\ THOMAS E. VAN METRE, JR. \\ (From the Department of Bacteriology, School of Hygiene and Public Health, and the \\ Department of Medicine, School of Medicine, The Johns Hopkins University)
}

(Received for publication August 9, 1948)

Evidence is accumulating that influenza virus plays a role in the etiology of certain pneumonias generally considered to be primarily bacterial in origin. The earliest recorded observations $(1,2)$ describe influenza as a mild self-limited disease of the upper respiratory tract which progressed occasionally in certain individuals to produce more serious symptoms involving the pulmonary tissue. Soon after the discovery of bacteria, clinicians (3) pointed out that pneumonia caused by streptococci, staphylococci and pneumococci often followed symptoms of influenza.

During the pandemic of 1918 influenza was frequently complicated by bacterial pneumonia. Certain investigators $(4,5)$ believed that the primary disease was of unknown virus etiology and that the pulmonary involvement was a manifestation of the secondary invasion of the respiratory tissues by pathogenic organisms.

Epidemiological data (6-10) show a significant increase in pneumonia deaths accompanying and following epidemics of clinical influenza. Other similar data $(11,12)$ indicate that localized epidemics of pneumococcus pneumonia have been associated with outbreaks of clinical influenza.

Laboratory evidence (13-22) on clinical cases of bacterial pneumonia in man and experiments on laboratory animals (23-28) during the past decade have further supported these observations.

The studies reported herein show that there was a simultaneous infection with pneumococci and influenza virus in about one-half of the human cases of lobar pneumonia studied during an influenza epidemic. Such mixed infections were also observed during interepidemic periods.

\footnotetext{
1 This study was supported in part by a grant from the Division of Research Grants and Fellowships, National Institutes of Health, U. S. P. H. S., Bethesda, Md.

2 Read in part at the annual meeting of the American Society for Clinical Investigation, May 3, 1948.
}

\section{MATERIAL AND METHODS}

\section{Source and preservation of specimens}

Sputum: Specimens of sputum were obtained from 69 cases of bacterial pneumonia admitted to hospitals in the Baltimore area between November 30, 1946 and August 5,1947 . The group included 61 cases of pneumococcal pneumonia, three cases of pneumonia due to Friedlander's bacillus, and five cases which were diagnosed clinically as bacterial pneumonia but in which the causative organism was not identified. Sixty-four were clinically lobar pneumonia and five were broncho-pneumonia. Sixty-two of the specimens were from the Osler Medical Clinic of The Johns Hopkins Hospital. These cases are believed to represent an unselected sample of the 75 cases of bacterial pneumonia which hospital records show were admitted to the Osler Clinic during this period. The other seven specimens were obtained from either Sinai Hospital or from the Veteran's Hospital, Fort Howard, Maryland.

Thirty-six of the 69 cases (52 per cent) occurred during March and April 1947, when influenza " $A$ " was known to be prevalent in the community as indicated by an increase in upper respiratory disease and by the frequent isolation of influenza virus. The occurrence of this outbreak afforded the opportunity to classify the cases into two groups (1) interepidemic, those occurring before and after March and April 1947, and (2) epidemic, those occurring during March and April. This classification with respect to the influenza epidemic is used throughout this report.

The sputa were mixed with beef heart infusion broth, $\mathrm{pH} 7.4$, and were either inoculated immediately into embryonated hen's eggs or were frozen in sealed glass ampoules and stored at $-20^{\circ} \mathrm{C}$ until they could be examined for the presence of influenza virus. The maximum period of storage was approximately four months.

Acute and convalescent sera: Acute and convalescent blood specimens were obtained from 53 of the 69 patients. The acute specimens were collected soon after admission to the hospital, and the convalescent specimens were secured just prior to discharge, approximately six to ten days later. A third specimen was collected about five months later from 25 of the cases. Serum from these specimens was inactivated by heating for 30 minutes at $56^{\circ} \mathrm{C}$, frozen in rubber stoppered glass ampoules and stored at $-20^{\circ} \mathrm{C}$ until it could be examined by the red cell agglutination-inhibition technique for antibody activity against various known strains of influenza virus. 
Autopsy material: Specimens of lung and bronchus were obtained at autopsy from 86 persons dying in Baltimore ${ }^{8}$ between December 1946 and October 1947. In addition one specimen was obtained from a person dying of pneumonia in May 1946. Of the 87 specimens, nine were from persons in whom death was believed to be due directly and primarily to pneumonia, 28 were from persons with pneumonia which was believed to be secondary to some other condition, and 50 were from persons who had no evidence of pneumonia. Classification was made on the basis of clinical and pathological data in the hospital and autopsy records. The group whose death was believed to be due primarily to pneumonia includes six cases of pneumococcal pneumonia and three cases which may not have been bacterial in origin since the causative organism was not identified. The group of secondary pneumonia consists of terminal or aspiration pneumonias and pneumonias first detected at autopsy. The third group includes only cases in which there was neither clinical nor pathological evidence of pulmonary pneumonia.

A 25 per cent suspension of the lung and bronchial tissue was made by emulsification with beef heart infusion broth in a Waring blender. The suspension was centrifuged to remove large particles of tissue and the supernatant was stored at $-20^{\circ} \mathrm{C}$ in sealed glass ampoules until it could be examined for the presence of influenza virus. The maximum period of storage was approximately six months.

\section{Virus isolation}

Both sputum and lung specimens were examined for influenza virus by the same technique. Five hundred units of penicillin and $5000 \mu \mathrm{g}$. of streptomycin were added to each milligram of the specimen and about 0.4 ml. of this mixture was inoculated into the amniotic sac (29) of 12 or 13 day old chick embryos. Ten embryos per specimen were used for the first egg passage and six for each additional passage.

The embryos were incubated at $35^{\circ} \mathrm{C}$ for four days. On the fourth day amniotic fluid and embryos were harvested. The amniotic fluid was tested for the presence of influenza virus by the pattern agglutination technique (30) using chick and guinea pig red blood cells. If the fluid was negative by this test the lungs and tracheas of the embryos were removed and ground in a mortar with the homologous amniotic fluid. Penicillin and streptomycin were added to the mixture and this material was passed amniotically to 12 or 13 day old embryos. Three egg passages were carried out before a specimen was considered negative.

In an attempt to detect possible laboratory cross infection six embryos were inoculated with sterile broth at the same time each group of specimens was examined. The broth control was carried along with the specimens through three egg passages of six embryos each.

${ }^{3}$ All autopsy specimens were obtained through the Department of Pathology of The Johns Hopkins Hospital and Medical School.

\section{Identification of viruses}

Amniotic fluids which gave positive tests by the pattern technique referred to above were inoculated into the allantoic sac of 10 or 11 day old chick embryos. Inoculated embryos were incubated for two days at $35^{\circ} \mathrm{C}$, chilled overnight at $4^{\circ} \mathrm{C}$, and the allantoic fluid harvested. Serial passage by the allantoic route was continued until allantoic fluid with a sufficient concentration of virus could be obtained for identification by the hemagglutination-inhibition test (31). A suitable antigen was usually obtained by the fourth egg passage.

Known influenza immune sera used in identification of viruses were prepared by subcutaneous inoculation of chickens with the following strains of influenza virus: the PR8 strain of influenza $A$, the Lee strain of influenza $B$, a strain of influenza A (F47A7) * isolated from an uncomplicated case of influenza during the 1947 epidemic in Baltimore, a strain of influenza A (P47A7) isolated from the lungs of a case of pneumonia in January 1947, and a strain of swine influenza virus.

Some of the strains, particularly those isolated during March and April 1947, proved difficult to identify as either A or B using this technique. Three of these strains (P47A2, P47A7, P47A8) were selected for further study employing acute and convalescent sera from cases of influenza occurring during three different epidemics: the 1943 influenza A epidemic, 5 the 1945 influenza B epidemic, and the 1947 influenza epidemic during which two of the three strains were isolated.

\section{Serological tests}

Serum was tested by the hemagglutination-inhibition technique (31) using known strains of influenza virus as antigen. The strains of influenza virus routinely used as antigen in these tests were the PR8 strain of influenza $A$, the Lee strain of influenza $B$, two recently isolated strains of influenza A (one [P47A2] from a fatal case of pneumonia occurring in January 1947 and one [F47A7] from an uncomplicated case of influenza in March 1947), a strain of influenza B (P47B2) from a case of pneumonia in January 1947, and a strain of swine influenza. In order to rule out the effects of variations in antigen concentration and variation in red cells used from time to time, all sera whose titers were to be compared were tested simultaneously.

4 The method of strain designation for influenza virus isolated in this laboratory is as follows: The first letter stands for the disease from which the virus was isolated ( $F=$ uncomplicated influenza; $P=$ pneumonia). The first two numbers represent the year of isolation. The second letter refers to the type of influenza virus ( $A=$ influenza $A ; B=$ influenza $B$ ). The last number is the order of isolation in the laboratory. Thus F47A7 is the seventh strain of influenza isolated in this laboratory in 1947 from uncomplicated influenza.

5 These sera were obtained through the courtesy of Dr. Thomas Francis, Jr., Ann Arbor, Michigan.

- Dr. Richard Shope, Princeton, New Jersey, kindly furnished his Strain 15. 
TABLE I

Influenza virus isolation and serological data on specimens collected from clinical cases of bacterial pneumonia

\begin{tabular}{c|c|c|c|c|c|r|r|r|r}
\hline \hline \multirow{2}{*}{$\begin{array}{c}\text { Time of occurrence with } \\
\text { respect to influenza }\end{array}$} & \multicolumn{3}{|c|}{ Virus isolation } & \multicolumn{3}{c|}{ Serological studies } & \multicolumn{3}{c}{ Total } \\
\cline { 2 - 8 } & No. & No. pos. & \% pos. & No. & No. pos. & \% pos. & No. & No. pos. & \% pos. \\
\hline $\begin{array}{c}\text { Interepidemic } \\
\text { Epidemic }\end{array}$ & 33 & 1 & 3 & 22 & 0 & 0 & 33 & 1 & 3 \\
47 & 13 & 36 & 33 & 12 & 37 & 36 & 17 & 47 \\
\hline
\end{tabular}

On the basis of serological results using the six antigens above, the cases of pneumonia were divided into four categories:

(1) Those in which the convalescent specimen when compared with the acute specimen showed a three-fold or more increase in titer to at least one of the strains of influenza A, but not to either strain of influenza B used as antigen.

(2) Those in which the convalescent specimen showed less than a three-fold increase in titer but in which the third specimen when compared with the convalescent specimen showed a four-fold or greater decrease in titer to at least one of the strains of influenza $A$, but not to either strain of influenza $B$.

(3) Those in which the third specimen when compared with the convalescent specimen showed at least a fourfold decrease in titer to both influenza $A$ and influenza $B$ antigens.

(4) Those in which there was neither a three-fold increase nor a four-fold decrease in titer to any of the antigens used in the test.

Since no specific increases or decreases in titer were obtained with the influenza $B$ antigens it is not necessary to include these categories.

The cases in Group 2 were classified as pneumonia with positive serological evidence of recent or concomitant infection with influenza A. Specific decrease in titer over a period of months has previously been used (15) as the basis for serodiagnosis of infection with influenza virus, but the procedure is not so well established as that of diagnosis on the basis of specific increases in titer over a short period of time from the acute stage of the disease to early convalescence. In this laboratory it was observed that in a number of instances the convalescent specimen when compared with the acute specimen showed a non-specific decrease in titer to all the antigens employed in the test. Sometimes as much as a three- or four-fold decrease was noted. The cause of this non-specific decrease is entirely unknown. Since such a decrease would tend to mask specific increases in titer it would not give false positive results in category number 1. It would, however, tend to magnify specific decreases in titer if the third specimen were compared with the acute specimen. For this reason in making positive diagnoses on the basis of decreases in titer, the third specimen was always compared with the second, or with the convalescent specimen rather than with the acute specimen. Because of the uncertainties involved in diagnosis on the basis of specific decreases in titer over a period of several months it was felt that only four-fold or greater decreases should be considered as serological evidence of infection with influenza virus.

The cases in Group 3 were classified as pneumonia with doubtful serological evidence of infection with influenza virus. Only two cases fell in this group. The significance of these doubtful results is difficult to determine. They may represent inherent inaccuracies in the test or they may be the result of anamnestic reactions. On the other hand, they may be indicative of actual infection with influenza virus. In the latter case their nonspecific nature might be explained either on the basis of infection with a strain of influenza virus with broad antigenic characteristics or on the basis of infection with more than one strain of influenza virus during the interval of several months.

The cases in Group 4 were classified as pneumonia with no serological evidence of infection with influenza virus.

\section{RESULTS}

\section{Clinical cases of bacterial pneumonia}

\section{Isolation of virus}

The results of both virus isolation and serological studies in the 69 cases of bacterial pneumonia investigated are shown in Table I.

Of the 33 specimens collected during the interepidemic period only one was positive by virus isolation. This was a specimen of sputum obtained on the fifth day of disease from a case of Type I pneumococcal lobar pneumonia occurring in January 1947. A strain of influenza B (P47B2) was isolated from this sputum on the first egg passage. Influenza virus was not isolated from a second sputum obtained on the seventh day of disease. On retesting the original sputum which had been stored at $-20^{\circ} \mathrm{C}$ for two weeks influenza $\mathrm{B}$ was again isolated on the first egg passage. The other strain of influenza B (P47B1) was isolated from the lungs of a fatal case of pneumonia which also occurred in January of 1947 . This case will be discussed later. During the interval between December 1945, at which time there was an epidemic of influenza B in Baltimore, and the time of isola- 
TABLE II

Day of disease on which sputum was collected and virus isolated from clinical cases of bacterial pneumonia

\begin{tabular}{c|c|c|c|c}
\hline \multirow{2}{*}{ Day of disease } & \multicolumn{4}{|c}{ Number of specimens } \\
\cline { 2 - 5 } & $\begin{array}{c}\text { Inter- } \\
\text { epidemic } \\
\text { periods }\end{array}$ & $\begin{array}{c}\text { Positive } \\
\text { for } \\
\text { influenza }\end{array}$ & $\begin{array}{c}\text { Epidemic } \\
\text { period }\end{array}$ & $\begin{array}{c}\text { Positive } \\
\text { for } \\
\text { influenza }\end{array}$ \\
\hline $\begin{array}{c}1-4 \\
5-9\end{array}$ & 21 & 1 & 20 & 7 \\
10 and over & 3 & 12 & 5 \\
Unknown & 33 & 1 & 36 & 1 \\
Total & 33 & 13 \\
\hline
\end{tabular}

tion of these two strains of influenza $B$, approximately 100 specimens of nasal washings from persons with upper respiratory infections had been inoculated into chick embryos. In no instance was influenza virus detected.

Influenza virus was isolated from 13 of the 36 cases of bacterial pneumonia which occurred during the influenza epidemic in March and April, 1947. The cases from which these strains of virus were isolated were all classified as pneumococcal pneumonia. Two were bronchopneumonia and the others were lobar pneumonia. Six were shown to be due to Type I, two to Type XXV, one to Type II, one to Type IV, and two to untyped pneumococci. Both Type IV and Type XXII were present in the sputum in one case. In these 13 positive cases sputum specimens were obtained from the first to the 20th day after the onset of clinical symptoms of pneumonia (see Table II).

In this small series of cases there is no correlation between day of disease and ability to isolate virus from sputum. The fact that virus was isolated from six specimens on or after the fifth day of pneumonia is somewhat surprising because it is generally believed that the virus is demonstrable in nasal or throat washings from uncomplicated influenza only early in the disease.

The isolation of influenza virus beyond the expected time in these complicated cases of mixed virus and bacterial infection may be explained on the basis that the virus in conjunction with the pathogenic bacterium descends to the lower respiratory tract, persists and probably multiplies in the respiratory epithelium of the bronchial tree longer than it ordinarily persists in the epithelial cells of the upper respiratory tract.

Appropriate precautions were taken to prevent laboratory cross infections leading to false posi- tive results. These are believed to have been adequate for the following reasons:

(1) All of the 13 strains isolated during the influenza epidemic were found to be similar to strains of influenza $A$ isolated from uncomplicated cases of influenza occurring in Baltimore during the same period.

(2) In each case the influenza virus was isolated on the first egg passage.

(3) All of the strains upon original isolation showed certain characteristics of the "O" type virus (32) in that they had a much higher agglutinating titer for guinea pig red blood cells than for chicken red blood cells.

(4) Twelve of the positive sputa were retested after they had been stored at $-20^{\circ} \mathrm{C}$ for approximately eight months. Virus was again isolated on the first egg passage from 11 of these. The 12th sputum was negative after two egg passages. It is believed that the long period of storage, during which time the specimens were allowed to thaw and refreeze at least once, might well account for the failure to reisolate influenza virus from this one case. The possibility that the first isolation of influenza virus from this sputum might have resulted from a laboratory cross infection must be considered. However, on original isolation this strain showed " $\mathrm{O}$ " characteristics, which usually do not persist beyond the first passage. Unfortunately, no second serum was obtained from this individual so that a confirmatory serological diagnosis could not be made.

(5) None of the 18 broth controls which were inoculated and passed in a manner similar to the sputum specimens was ever shown to be contaminated with virus.

(6) All strains gave low hemagglutination titers in the early egg passages which increased for five to six passages.

\section{Serological studies}

Acute and convalescent serum specimens were obtained from 22 of the 33 cases which occurred in the interepidemic periods. A third specimen was obtained from 10 of these. There were no positive serological results in this group. The three specimens of serum obtained from the one case which was positive by virus isolation gave negative results by all serological tests including the 
test in which the homologous virus was used as antigen. This may be an indication that the influenza virus played no part in this particular patient's illness. However, it has been noted that a certain proportion of persons who have clinical influenza during proved influenza epidemics fail to show an antibody response (33-38). In this connection it is interesting to note that of 45 cases of uncomplicated influenza occurring during the 1947 epidemic from which virus was actually isolated, only 21 (39) showed a significant increase in titer when tested by the agglutination-inhibition technique. Therefore, it seems reasonable to believe that the influenza $B$ virus might have played a part in the disease process even though it caused no increase in serum antibody content as measured by the hemagglutination-inhibition test.

There were two doubtful results obtained on the specimens in the interepidemic group. A case of clinical lobar pneumonia of undetermined cause, which occurred in February 1947, was tested serologically five months later and showed a four-fold decrease in titer to a current strain of influenza $\mathrm{A}$ as well as a six-fold decrease in titer to the Lee strain of influenza B. Another case of lobar pneumonia believed to be due to Type VIII pneumococcus, which occurred in July 1947 , showed a decrease in titer to both influenza $\mathrm{A}$ and influenza $\mathrm{B}$ antigens after a period of three months.

Acute and convalescent serum specimens were obtained from 33 of the 36 cases which occurred during the 1947 epidemic of influenza A. A third specimen was obtained from 15 of these. Twelve positive serological results were obtained in these cases, 10 falling into Group 1 as described above, and two into Group 2. Of the 10 cases in which the convalescent specimen showed at least a threefold increase to influenza $A$ antigens seven were also positive by virus isolation. As previously stated these seven cases were pneumococcal pneumonia due to various types of pneumococci. The other three were also due to pneumococci. All three were classified clinically as lobar pneumonia. One was due to Type I and one to Type II. Both Type III and Type XI were present in the sputum of the third case. Of the two cases diagnosed serologically on the basis of a specific four-fold decrease, one was also positive by virus isolation. Both these cases were pneumococcal lobar pneumonia, Type I.
No doubtful results were obtained in the epidemic group. Twenty-three specimens, including three which were positive by virus isolation, were negative serologically.

Of the four strains of influenza A routinely used as antigen in the agglutination-inhibition test by far the greatest number of positive results were obtained with P47A2, a strain of influenza $\mathrm{A}$ isolated from the lungs of a fatal case of pneumonia which occurred in February 1947. Nine of the ten cases which fell into the first group of serological positives showed a three-fold or more increase in titer with this antigen. Seven of the ten were positive with F47A7, a strain of influenza A isolated from a clinical case of influenza in March 1947 and chosen in this laboratory as the reference 1947 influenza A strain. Only two of the ten showed a three-fold or more increase to PR8, and one showed a significant increase with a strain of swine influenza virus. Table III shows the results of ten serologically positive cases with the four influenza A antigens.

In summary, of the 33 cases in the interepidemic periods one was positive by virus isolation and none was positive by serological methods. Of the 36 cases in the epidemic period 13, or 36 per cent, were positive by virus isolation. Eight of these 13 were also positive by serological tests. In addition to these eight, four cases were positive by serological results but negative by virus isolation. Thus, a total of 17 cases, or 47 per cent of those occurring during the influenza epidemic, gave posi-

TABLE III

\begin{tabular}{|c|c|c|c|c|}
\hline \multirow{2}{*}{ Specimen number } & \multicolumn{4}{|c|}{$\begin{array}{c}\text { Convalescent titer/acute titer with } \\
\text { various antigens }\end{array}$} \\
\hline & PR8 & Swine & F47A7 & P47A2 \\
\hline $\begin{array}{l}367 \\
388 \\
390 \\
396 \\
406 \\
413 \\
424 \\
427 \\
434 \\
435\end{array}$ & $\begin{array}{r}6.1 \\
13.0 \\
2.0 \\
2.3 \\
2.6 \\
0.6 \\
1.1 \\
0.8 \\
2.5 \\
0.7\end{array}$ & $\begin{array}{l}4.3 \\
2.1 \\
0.6 \\
1.5 \\
0.5 \\
0.7 \\
0.4 \\
2.3 \\
0.4\end{array}$ & $\begin{array}{r}3.0 \\
21.0 \\
4.6 \\
7.0 \\
1.4 \\
5.2 \\
0.9 \\
2.0 \\
3.2 \\
3.0\end{array}$ & $\begin{array}{r}3.0 \\
40.0 \\
10.0 \\
10.0 \\
12.0 \\
3.0 \\
7.3 \\
8.0 \\
3.3 \\
0.6\end{array}$ \\
\hline Total positive & 2 & 1 & 7 & 9 \\
\hline
\end{tabular}


tive evidence of the presence of influenza virus associated with lobar pneumonia. All of these 17 cases were pneumococcal pneumonia. Eight were classified as Type I, two as Type XXV and one each as Types II, IV and XXII. Both Types III and XI were present in the sputum of one and Types IV and XXII in the sputum of another. Two cases were due to pneumococci whose type was not determined.

\section{Virus isolation from autopsy material}

The results of virus isolation from autopsy material are shown in Table IV.

TABLE IV

Influenza virus isolations from specimens of lung and bronchus obtained at autopsy from patients with pneumonia and with no pneumonia

\begin{tabular}{l|r|r|r|r|r|r}
\hline \hline \multirow{2}{*}{ Classification } & \multicolumn{2}{|c|}{$\begin{array}{c}\text { Epidemic } \\
\text { period }\end{array}$} & \multicolumn{2}{|c|}{$\begin{array}{c}\text { Inter- } \\
\text { epidemic } \\
\text { period }\end{array}$} & \multicolumn{2}{|c}{ Total } \\
\cline { 2 - 6 } & $\begin{array}{r}\text { No. } \\
\text { cases }\end{array}$ & $\begin{array}{c}\text { No. } \\
\text { pos. }\end{array}$ & $\begin{array}{c}\text { No. } \\
\text { cases }\end{array}$ & $\begin{array}{c}\text { No. } \\
\text { pos. }\end{array}$ & $\begin{array}{c}\text { No. } \\
\text { cases }\end{array}$ & $\begin{array}{l}\text { No. } \\
\text { pos. }\end{array}$ \\
\hline $\begin{array}{l}\text { Primary pneumonia } \\
\text { Secondary pneumonia }\end{array}$ & 2 & 0 & 7 & 2 & 9 & 2 \\
No pneumonia & 26 & 0 & 21 & 2 & 28 & 2 \\
\hline
\end{tabular}

Influenza virus was isolated from two of the nine fatal cases classified as primary pneumonia. Both pneumococcus Type II and a strain of influenza $A$ were isolated from the lungs of one of these cases (P46A1) which occurred in May 1946. In order to determine the quantity of virus present in the lungs of this case, titrations were made by inoculating chick embryos both by the allantoic route and by the amniotic route. The dose which would infect 50 per cent of the embryos inoculated was calculated using the method proposed by Reed and Muench (40). The EID $_{50}$ for 11 day chick embryos inoculated via the allantoic route was $10^{-7.8}$. For 13 day embryos inoculated by the amniotic method an $\mathrm{EID}_{50}$ of $10^{-8.3}$ was obtained. These data indicate that virus was present in large quantities.

At the time of occurrence of this case, clinical and epidemiological evidence indicated that influenza A had not been prevalent in Baltimore for $2 \frac{1}{2}$ years and laboratory studies on upper respiratory disease for at least six months prior to the case had not disclosed influenza $\mathrm{A}$ in the population.
In Jaunary, 1947, in Baltimore, one year after the last known clinical case of influenza $B$, a strain of influenza $B$ was isolated from the lungs of another fatal case of pneumonia (P47B1) and pneumococcus Type XI was isolated from the tracheal exudate three days before death.

The clinical and pathological aspects of these two cases will be discussed in another paper (41).

Influenza virus was isolated from the lungs of two of the 28 cases classified as secondary pneumonia. Both of the cases occurred early in February, just one month prior to the influenza $\mathrm{A}$ epidemic in Baltimore. One of the two strains (P47A1) of virus isolated was similar to strains isolated from clinical cases of influenza A during the epidemic. The other strain (P47A2) was also influenza $A$ but it differed antigenically from the epidemic strain.

Lack of data makes it impossible to determine the exact nature of the pulmonary involvement of these two cases. There is, however, evidence in both cases which indicates that there was some pulmonary involvement. Since these cases will not be included in the subsequent paper a brief resume of the clinical and pathological data is given here.

One of the patients (P47A1), a colored male 14 months old, entered Sydenham Hospital with a diagnosis of chicken pox from the Harriet Lane Home of The Johns Hopkins Hospital. On admission his temperature was 103, pulse 176 and respirations 44 . The uvula, the tonsils and the posterior pharynx were injected. The lungs were clear. The patient was given penicillin. After four days the temperature was normal and the throat injection had subsided. A systolic murmur was present over the base of the heart. Subsequently, this became more pronounced, spreading to the apex. On the ninth hospital day the patient died. The final clinical diagnosis was heart failure of unknown etiology, healed varicella, otitis media, and acute pharyngitis.

At autopsy wide-spread collapse in the posterior parts of both lungs was noted. There were small scattered areas of what appeared to be consolidation. The right auricle and ventricle were much enlarged.

Sections of the lung showed a condition compatible with chronic passive congestion. There were also small scattered foci of coagulative necrosis. The fresher ones seemed to be composed of 
fibrin, a few mononuclear cells and some hemorrhage. The walls of the alveoli in these areas were necrotic. These lesions were said to be not unlike those previously observed (42) in a case of congenital varicella.

Unfortunately, no cultures were made from this lung and it is impossible to determine what part, if any, pathogenic organisms might have played in the disease process. It is also impossible to determine whether or not influenza virus itself played any part in the formation of the lung lesions found at autopsy.

The other fatal case (P47A2) classified as secondary pneumonia from which a strain of influenza A was isolated was a white male seven months old. This patient was referred to Sydenham Hospital with a diagnosis of bronchopneumonia of one day's duration. He was dead on arrival at the hospital. A cisternal tap showed cloudy fluid containing $H$. influenzae. The patient's older brother who was brought to the hospital at the same time was subsequently shown to have had meningitis due to $H$. influenzae.

At autopsy the lungs were found to be mostly air-containing. The pleural surfaces were smooth. The bronchial mucosa was covered by thin mucoid material. On section the cut surfaces of the lungs showed numerous grayish areas separated by areas of red. In some areas the foci of consolidation appeared to be around the walls of the small bronchi.

Histological examination of these lungs failed to show any evidence of consolidation, bronchitis, or interstitial pneumonia.

As in the previous case no cultures from the lungs were reported. A culture made in this laboratory revealed no significant pathogen but the plates were contaminated with a gram negative rod believed to be Aerobacter aerogenes.

Titrations in chick embryos were made to determine the quantity of virus in this lung. The $\mathrm{EID}_{50}$ was $10^{-2.8}$ with 11 day embryos inoculated allantoically. This is a minimum figure since the titration was made after the specimen of lung had been stored for six months at $-20^{\circ} \mathrm{C}$. During the storage period the specimen was known to have been thawed and refrozen at least once. The quantity of virus in the lung was therefore sufficient to suggest that the virus might have become established in the lung tissue. The role it played, either alone or with some undetermined bacterial agent,

TABLE V

Serological study of strains of influenza virus isolated from cases of bacterial pneumonia using serum from chickens immunized with known strains of influenza virus

\begin{tabular}{|c|c|c|c|c|c|c|c|c|}
\hline \multirow{2}{*}{$\begin{array}{l}\text { Strain of } \\
\text { virus }\end{array}$} & \multirow{2}{*}{ Source } & \multirow{2}{*}{$\begin{array}{c}\text { Date of } \\
\text { isolation }\end{array}$} & \multicolumn{6}{|c|}{ Hemagglutination-inhibition titer with specific immune chicken sera } \\
\hline & & & PR8 & Lee & Swine & F47A7 & IIP47A2 & P47A7 \\
\hline $\begin{array}{l}\text { PR8 } \\
\text { Lee } \\
\text { Swine } \\
\text { F47A7 } \\
\text { P46A1* } \\
\text { P47B1 } \\
\text { P47A1* } \\
\text { P47A2 } \\
\text { P47B2 } \\
\text { P47A3* } \\
\text { P47A4 } \\
\text { P47A5 } \\
\text { P47A6 } \\
\text { P47A7 } \\
\text { P47A8 } \\
\text { P47A9 } \\
\text { P47A10 } \\
\text { P47A11 } \\
\text { P47A12 } \\
\text { P47A13 } \\
\text { P47A14 } \\
\text { P47A15 }\end{array}$ & $\begin{array}{l}\text { Clinical influenza } \\
\text { Fatal pneumonia } \\
\text { Fatal pneumonia } \\
\text { Fatal pneumonia } \\
\text { Fatal pneumonia } \\
\text { Nonfatal pneumonia } \\
\text { Nonfatal pneumonia } \\
\text { Nonfatal pneumonia } \\
\text { Nonfatal pneumonia } \\
\text { Nonfatal pneumonia } \\
\text { Nonfatal pneumonia } \\
\text { Nonfatal pneumonia } \\
\text { Nonfatal pneumonia } \\
\text { Nonfatal pneumonia } \\
\text { Nonfatal pneumonia } \\
\text { Nonfatal pneumonia } \\
\text { Nonfatal pneumonia } \\
\text { Nonfatal pneumonia } \\
\text { Nonfatal pneumonia }\end{array}$ & $\begin{array}{l}\text { March } 1947 \\
\text { May } 1946 \\
\text { Jan. } 1947 \\
\text { Feb. } 1947 \\
\text { Feb. } 1947 \\
\text { Jan. } 1947 \\
\text { March } 1947 \\
\text { March } 1947 \\
\text { March } 1947 \\
\text { March } 1947 \\
\text { March } 1947 \\
\text { March } 1947 \\
\text { March } 1947 \\
\text { April } 1947 \\
\text { April } 1947 \\
\text { April } 1947 \\
\text { April } 1947 \\
\text { April } 1947 \\
\text { April } 1947\end{array}$ & $\begin{array}{r}1670 \\
69 \\
52 \\
147 \\
182 \\
49 \\
128 \\
147 \\
32 \\
169 \\
208 \\
128 \\
294 \\
84 \\
239 \\
182 \\
208 \\
223 \\
779 \\
138 \\
91 \\
97\end{array}$ & $\begin{array}{r}128 \\
588 \\
32 \\
56 \\
32 \\
338 \\
169 \\
32 \\
169 \\
194 \\
256 \\
64 \\
182 \\
39 \\
208 \\
256 \\
112 \\
194 \\
1270 \\
338 \\
104 \\
79\end{array}$ & $\begin{array}{r}182 \\
169 \\
1560 \\
91 \\
112 \\
45 \\
\frac{1}{104} \\
32 \\
120 \\
208 \\
79 \\
182 \\
52 \\
256 \\
60 \\
158 \\
120 \\
512 \\
169 \\
52 \\
32\end{array}$ & $\begin{array}{r}120 \\
42 \\
37 \\
835 \\
64 \\
32 \\
1175 \\
74 \\
32 \\
1350 \\
779 \\
588 \\
1450 \\
417 \\
1560 \\
779 \\
722 \\
958 \\
2200 \\
512 \\
512 \\
388\end{array}$ & $\begin{array}{r}338 \\
45 \\
49 \\
512 \\
779 \\
128 \\
362 \\
32 \\
\overline{56} \\
169 \\
388 \\
208 \\
512 \\
417 \\
239 \\
479 \\
891 \\
588 \\
294 \\
182\end{array}$ & $\begin{array}{r}388 \\
417 \\
37 \\
549 \\
256 \\
128 \\
32 \\
32 \\
512 \\
223 \\
479 \\
447 \\
512 \\
223 \\
417 \\
447 \\
588 \\
294 \\
128 \\
91\end{array}$ \\
\hline
\end{tabular}

* All except these tests were run simultaneously. 
in the production of the clinical symptoms cannot be determined on the basis of available data.

\section{Strain identification}

The results of hemagglutination-inhibition tests using known immune chicken sera with the various strains of virus isolated from sputum or lung specimens are shown in Table V.

Interpretation of these data is very difficult since the homologous titers of the various immune sera were different and since there was some unavoidable variation in the quantities of the different antigens used in the test.

It seems clear, however, that of the four strains isolated from the lungs of fatal cases of pneumonia one (P47B1) was a typical strain of influenza B and two (P46A1 and P47A2) were strains of influenza A which immunologically were very similar to each other, and somewhat similar to the PR8 strain of influenza A. Neither of these strains showed cross reactions with the Lee strain of influenza B. The fourth strain (P47A1) was inhibited to almost the same extent by both PR8 chicken antiserum and Lee chicken antiserum. It was inhibited by much higher dilutions of chicken antiserum to the strain chosen in this laboratory because of its early isolation and its antigenic similarity to subsequently isolated strains as the reference 1947 strain of influenza A (F47A7).

Of the 14 strains isolated from the sputum of nonfatal cases of pneumonia, one (P47B2) was a typical strain of influenza $B$. The other 13 strains, all isolated in March and April, 1947, were similar to each other and to the reference 1947 strain of in- fluenza A (F47A7). They were inhibited to almost the same extent both by PR8 chicken antiserum and by Lee chicken antiserum.

The tests described above were carried out after the various strains had been passed only three or four times in chick embryos. Since it is known that antigen prepared from recently isolated strains may contain a substance which inhibits the agglutination of red blood cells in the presence of normal as well as immune sera (57) three strains (P47A2, P47A8 and P47A7) were selected for further study after repeated passages in chick embryos. After 12 embryo passages, the results were essentially the same as those obtained using antigens prepared from earlier egg passage material. Strain P47A2 was again inhibited, although to a small extent, by PR8 antiserum but not by Lee antiserum. Strains P47A7 and P47A8 were inhibited to almost the same extent by both PR8 antiserum and by Lee antiserum. They were inhibited to a greater extent by F47A7 antiserum.

By using the unidentified strains of virus as antigens in hemagglutination-inhibition tests with human acute and convalescent sera obtained from persons who had clinical influenza during three different proved influenza epidemics, somewhat more clear-cut results were obtained. The results of these tests are shown in Table VI.

On the basis of the results obtained with human acute and convalescent sera, the strains of influenza virus isolated from patients with pneumonia during the 1947 epidemic of influenza in Baltimore are believed to be more closely related to influenza $A$ than to influenza $B$ and to be very closely related to strains of influenza virus isolated

TABLE VI

Identification of selected strains of influenza virus using human acute and convalescent sera from three influenza epidemics

\begin{tabular}{c|c|r|r|r|r|r|r}
\hline \hline \multirow{2}{*}{$\begin{array}{c}\text { Serum } \\
\text { secimen } \\
\text { number }\end{array}$} & Source of serum & \multicolumn{5}{|c|}{ Convalescent titer/acute titer with various antigens } \\
\cline { 2 - 8 } & & PR8 & Lee & P47A2 & F47A7 & P47A7 & P47A8 \\
\hline 1 & 1943 influenza A epidemic & 5.0 & 1.2 & 5.2 & 1.2 & 1.6 & 1.1 \\
2 & 1943 influenza A epidemic & 8.5 & 1.8 & 13.1 & 2.5 & 3.2 & 1.2 \\
3 & 1943 influenza A epidemic & 2.1 & 1.1 & 5.0 & 2.6 & 2.6 & 2.8 \\
4 & 1943 influenza A epidemic & 9.1 & 1.1 & 17.3 & 2.3 & 4.6 & 2.3 \\
5 & 1945 influenza B epidemic & 1.3 & 5.7 & 1.3 & 0.7 & 0.7 & 1.0 \\
6 & 1945 influenza B epidemic & 1.3 & 16.0 & 1.2 & 1.0 & 1.2 & 1.0 \\
7 & 1945 influenza B epidemic & 1.3 & 24.0 & 1.6 & 1.1 & 1.1 & 0.8 \\
8 & 1947 influenza A epidemic & 10.0 & 1.0 & 16.0 & 5.3 & 9.2 & 8.0 \\
9 & 1947 influenza A epidemic & 3.5 & 1.2 & 60.0 & 10.0 & 7.0 & 9.3 \\
10 & 1947 influenza A epidemic & 7.0 & 1.4 & 3.7 & 5.7 & 5.3 & 8.0 \\
\hline
\end{tabular}


from uncomplicated cases of influenza occurring during the same period.

\section{DISCUSSION}

It seems evident on the basis of results obtained in these and other similar studies that often during influenza epidemics and occasionally during nonepidemic periods, bacterial pneumonia is in some way related to recent or concurrent infection with influenza virus. The pathogenesis of these multiple infections is not yet understood.

It seems unlikely that influenza virus alone is often responsible for severe pneumonia. During the 1918 pandemic a vast number of fatal cases of pneumonia were examined $(4,43-47)$ and in only two reported instances (47) was it impossible to isolate a pathogenic organism from the lungs. Since the discovery of the virus etiology of influenza a number of successful attempts have been made to isolate the virus from the lungs of fatal cases of pneumonia. In all but one of these (18) a pathogenic organism was also present in the lungs.

No pathogenic organism was isolated from the lungs of one of the fatal cases reported in detail in another paper (41) and the pathology in this case is that of pure virus pneumonia. A pneumococcus Type XI was isolated, however, from the tracheal exudate three days before the patient died of bronchopneumonia.

Influenza virus has been isolated from the sputum of non-fatal cases of pneumonia. In most instances the predominating organisms in the sputum from these patients were pneumococci or hemolytic staphylococci. However, there is clinical evidence that infections with influenza virus alone can cause slight abnormal pulmonary signs and might actually cause some patchy consolidation $(22,48)$. Reimann (49) in a review of pneumonias of viral origin states that pneumonia is an integral part of influenza but for unknown reasons influenzal lesions of the lung are more often invaded by pathogenic organisms than are the lesions of other viral pneumonias.

Probably the most generally accepted explanation concerning the relationship of influenza virus and bacteria in the pneumonias accompanying influenza is that the viral agent plays only a preparatory role. It is commonly believed that debilitating infections such as influenza decrease the general resistance of the host and predispose to bacterial invasion. The mechanism by which general host resistance is lowered is not understood. A more clear-cut explanation for the lowering of local resistance in the respiratory tract can be given. It is known that influenzal infections in the ferret (50) and probably in the human (51) cause destruction of the ciliated epithelium of the respiratory tract. The destruction of this important local defense mechanism would be expected to facilitate invasion of the lungs by pathogenic organisms. Symptoms of pneumonia often have their onset a week or more after the first symptoms of influenza.

Although there is only slight evidence (26) to support such a concept, there is a possibility that the virus might act on certain potentially pathogenic organisms composing the normal flora of the nasopharynx in such a way as to increase their virulence and invasive ability. The invasive ability might be enhanced simply by the protective action against phagocytosis offered by mucus present as a result of influenzal infection. As reported herein, the isolation of influenza virus from 36 per cent of bacterial pneumonias occurring during an influenza epidemic indicates that the virus could have been playing an active part in the disease despite the onset of the pneumonia several days after the onset of clinical influenza. Both agents may be actively engaged in some as yet unknown relationship. Pathological manifestations of virus and bacterial complex infections are often similar regardless of the type of bacterium. The virus is thought to play a part in producing the pathological lesions and superimposed on such lesions are changes brought about by the bacterium.

Taylor (52) observed that a sublethal dose of influenza virus kills mice if followed in a day or two by intranasal instillation of sterile fluid. $\mathrm{He}$ proposed that the sterile fluid upset a delicate hostparasite relationship between spread of the virus and antibody production. By analogy such a mechanism might explain the simultaneous bacterial and influenza infections in man.

The inflammation produced by the bacterium may enhance release of the influenza virus from infected cells and aid in the spread of the virus to uninfected cells before the production of sufficient antibodies could prevent such a spread.

It is interesting to note that in five instances in the present study influenza virus was isolated from cases of pneumonia during interepidemic pe- 
riods with respect to influenza. Sporadic cases of influenza have been reported by several investigators $(20,53-56)$ but there is not yet general agreement concerning the whereabouts of influenza virus between epidemic periods. Further investigation of bacterial pneumonias during periods when uncomplicated cases of influenza are not occurring to any great extent might indicate that influenza is indeed an endemic disease reaching epidemic proportions at more or less regular intervals. Why it was possible to isolate influenza virus from the sputum or lung of five cases of pneumonia and not possible to demonstrate the virus in nasal washings in any of about 100 cases of uncomplicated upper respiratory infections during the same interepidemic periods is not known. It may be that in cases of complex infection the virus descends to the lower respiratory tract and proliferates longer than it would in the upper respiratory epithelium. The number of uncomplicated cases from which nasal washings were examined represents only a small fraction of all the upper respiratory infections which occurred during the interepidemic periods and it is possible that more extensive studies would reveal sporadic cases of uncomplicated influenza as well as influenza complicated by pneumonia.

While these studies have been concerned with the simultaneous occurrence of influenza virus and bacteria in pneumonia, it is difficult to resist the speculation that other respiratory viruses, if and when techniques are available for their ready isolation and identification, will also be found in association with bacteria in other cases of pneumonia in man.

\section{SUM MARY}

1. Seventeen of 36 cases of pneumococcal pneumonia occurring during an epidemic of influenza A in Baltimore in March and April, 1947, yielded positive evidence, either by virus isolation or by serological studies of recent or concurrent infection with influenza virus.

2. All of the 13 strains of influenza virus isolated from these 36 cases were found to be similar to strains of virus isolated from uncomplicated cases of influenza occurring during the same period.

3. Influenza virus was isolated from the sputum of one of 33 cases of bacterial pneumonia oc- curring during interepidemic periods. The one positive specimen was from a case of pneumococcal lobar pneumonia and the virus isolated was a typical strain of influenza B.

4. The lungs of two fatal cases of primary pneumonia and two cases of secondary pneumonia, in which no pathogenic organism was identified, yielded influenza virus. Three of the strains of virus were influenza $A$ and one was influenza $B$. All four of these cases occurred during interepidemic periods with respect to influenza.

5. These studies indicate that influenza virus plays a role in the etiology of certain pneumonias which have hitherto been considered primarily bacterial in origin.

\section{BIBLIOGRAPHY}

1. Hirsch, August, Handbook of geographical and historical pathology. Vol. I. Tr. from 2nd German edition by C. Creighton, The New Sydenham Society, London, 1883.

2. Thompson, Theophilus, Annals of influenza or epidemic catarrhal fever in Great Britain from 1510 to 1837. The New Sydenham Society, London, 1852.

3. Althaus, Julius, Influenza. Longmans and Co., London, 1892, Ed. 2.

4. MacCallum, W. G., The Pathology of Pneumonia in the United States Army Camps during the Winter of 1917-1918. The Rockefeller Institute for Medical Research, Monograph No. 10, New York, 1919.

5. MacCallum, W. G., A Textbook of Pathology. W. B. Saunders Co., Philadelphia, 1940, 7th Ed.

6. Collins, S. D., Influenza-pneumonia mortality in a group of about 95 cities in the United States 19201929. Pub. Health Rep., 1930, 45, 361.

7. Collins, S. D., and Gover, M., Influenza and pneumonia mortality in a group of about 95 cities in the United States during four minor epidemics 1930-1935, with a summary for 1920-1935. Pub. Health Rep., 1935, 50, 1668.

8. Gover, M., Influenza and pneumonia mortality in a group of 90 cities in the United States, August 1935-March 1943. Pub. Health Rep., 1943, 58, 1033.

9. Collins, S. D., Influenza and pneumonia excess mortality at specific ages in the epidemic of 1943-44 with comparative data for preceding epidemics. Pub. Health Rep., 1945, 60, 821.

10. Koller, S., Der jahrzeitliche Gang der Sterblichkeit an Krankheiten des Kreislaufs mit der Antmungsorgane. II. Der Verlauf in Jahren mit und ohne Grippeepidemic. Arch. f. Kreislaufforsch., 1941, 8, 296.

11. Commission on Acute Respiratory Diseases and the New York State Department of Health, Albany: 
The relation between epidemics of acute bacterial pneumonia and influenza. Science, 1945, 102, 561.

12. Smillie, G. H., Warnock, G. H., and White, H. J., A study of a Type I pneumococcus epidemic at the State Hospital at Worcester, Mass. Am. J. Pub. Health, 1938, 28, 293.

13. Stuart-Harris, C. H., Andrews, C. H., and Smith, W., A Study of Epidemic Influenza: With Special Reference to the 1936-37 Epidemic. Medical Research Council Special Report, Series No. 228. His Majesty's Stat. Off., London, 1938.

14. Stokes, J., Jr., and Wolman, I. J., The probable synergism of human influenza virus and Staphylococcus aureus in a rapidly fatal respiratory infection. Internat. Clin., 1940, 1, 115.

15. Pearson, H. E., Eppinger, E. G., Dingle, J. H., and Enders, J. F., A study of influenza in Boston during the winter of 1940-41. New England J. Med., 1941, 225, 763.

16. Michael, M., Jr., Staphylococcus aureus pneumonia with special reference to its occurrence as a complication of influenza. J. A. M. A., 1942, 118, 869.

17. Himmelweit, F., Influenza virus $B$ isolated from a fatal case of pneumonia. Lancet, 1943, 2, 793.

18. Finland, M., Barnes, M. W., and Samper, B. A., Influenza virus isolation and serological studies made in Boston during winter 1943-44. J. Clin. Invest., 1945, 24, 192.

19. Parker, F., Jolliffe, L. S., Barnes, M. W., and Finland, M., Pathological findings in the lungs of five cases from which influenza virus was isolated. Am. J. Path., 1946, 22, 797.

20. Dudgeon, J. A., Stuart-Harris, C. H., Andrews, C. H., Glover, R. E., and Bradley, W. H., Influenza $B$ in 1945-46. Lancet, 1946, 2, 627.

21. Burnet, F. M., Stone, J. D., and Anderson, S. G., An epidemic of influenza B in Australia. Lancet, 1946, 1, 807.

22. Finland, M., Ory, E. M., Meads, M., and Barnes, M. W., Influenza and pneumonia. Serological studies during and after an outbreak of influenza B. J. Lab. \& Clin. Med., 1948, 33, 32.

23. Shope, R. E., and Francis, T., The susceptibility of swine to the virus of human influenza. J. Exper. Med., 1936, 64, 791.

24. Brightman, I. J., Streptococcus infection occurring in ferrets inoculated with human influenza virus. Yale J. Biol. \& Med., 1935, 8, 127.

25. Glover, R. E., Spread of infection from the respiratory tract of the ferret. II. Association of influenza $A$ virus and Streptococcus group C. Brit. J. Exper. Path., 1941, 22, 98.

26. Francis, T., and De Torregrosa, M. V., Combined infection of mice with $H$. influenzae and influenza virus by the intranasal route. J. Infect. Dis., $1945,76,70$.

27. Harford, C. G., Smith, M. R., and Wood, W. B., Jr., Sulfonamide chemotherapy of combined infection with influenza virus and bacteria. J. Exper. Med., 1946, 83, 505.
28. Schwab, J. L., Blubaugh, F. C., and Woolpert, O. C., The response of mice to intranasal inoculation of mixtures of streptococcus hemolyticus and influenza virus. J. Bact., 1941, 41, 59.

29. Taylor, R. M., and Chialvo, R. J., Simplified technique for inoculating into the amniotic sac of chick embryos. Proc. Soc. Exper. Biol. \& Med., 1942, $51,328$.

30. Salk, J. E., A simplified procedure for titrating hemagglutination capacity of influenza virus and the corresponding antibody. J. Immunol., 1944, 49, 87.

31. Hirst, G. K., The quantitative determination of influenza virus and antibodies by means of red cell agglutination. J. Exper. Med., 1942, 75, 49.

32. Burnet, F. M., and Bull, D. R., Changes in influenza virus associated with adaptation to passage in chick embryos. Australian J. Exper. Biol. \& M. Sc., 1943, 21, 55.

33. Rickard, E. R., Thigpen, M., and Crowley, J. H., Vaccination against influenza at the University of Minnesota. Am. J. Hyg., 1945, 42, 12.

34. Hirst, G. K., Plummer, N., and Friedewald, W. F., Human immunity following vaccination with formalized influenza virus. Am. J. Hyg., 1945, 42, 45.

35. Stuart-Harris, C. H., Observations on the agglutination of fowl red cells by influenza viruses. Brit. J. Exper. Path., 1943, 24, 33.

36. Adams, J. M., Thigpen, M. P., and Rickard, E. R., An epidemic of influenza $A$ in infants and children. J. A. M. A., 1944, 125, 473.

37. Crowley, J. H., Thigpen, M. P., and Rickard, E. R., Isolation of influenza $A$ virus from normal human contacts during an epidemic of influenza A. Proc. Soc. Exper. Biol. \& Med., 1944, 57, 354.

38. Magill, T. P., Plummer, N., Smillie, W. G., and Sugg, J. Y., An evaluation of vaccination against influenza. Am. J. Hyg., 1945, 42, 94.

39. Ward, Thomas G. (unpublished data).

40. Reed, L. J., and Muench, H., A simple method of estimating 50 percent endpoints. Am. J. Hyg., 1938, 27, 493.

41. Van Metre, T. E., Jr., Ward, T. G., and Maxwell, E. S., To be published.

42. Oppenheimer, E. H., Congenital chicken pox with disseminated visceral lesions. Bull. Johns Hopkins Hosp., 1944, 74, 240.

43. Wolbach, S. B., Comments on the pathology and bacteriology of fatal influenza cases as observed at Camp Devens, Mass. Bull. Johns Hopkins Hosp., 1919, 30, 104.

44. Chickering, H. T., and Park, J. H., Staphylococcus aureus pneumonia. J. A. M. A., 1919, 72, 617.

45. Opie, E. L., Blake, F. G., Small, J. C., and Rivers, T. M., Epidemic Respiratory Diseases. The Pneumonias and Other Infections of the Respiratory Tract Accompanying Influenza and Measles. C. V. Mosby Co., St. Louis, 1921.

46. Winternitz, M. G., Wason, I. M., and McNamara, F. P., The Pathology of Influenza. Yale University Press, New Haven, 1920. 
47. Goodpasture, E. W., The significance of certain pulmonary lesions in relation to the etiology of influenza. Am. J. Med. Sc., 1919, 158, 863.

48. Scadding, J. G., Lung changes in influenza. Quart. J. Med., 1937, 6, 425.

49. Reimann, H. A., The viral pneumonias and pneumonia of probable viral origin. Medicine, 1947, 26, 167.

50. Francis, T., and Stuart-Harris, C. H., Studies on the nasal histology of epidemic influenza virus infection in the ferret. J. Exper. Med., 1938, 68, 789.

51. Adams, J. M., Pennoyer, M. M., and Whiting, A. M., Pathologic study of the acutely inflamed human pharynx in influenza $A$ infection. Am. J. Dis. Child., 1946, 71, 162.

52. Taylor, R. M., Experimental infection with influenza $A$ virus in mice-the increase in intrapulmonary virus after inoculation and the influence of various factors thereon. J. Exper. Med., 1941, 73, 43.

53. Salk, J. E., Menke, W. J., and Francis, T., Identification of influenza virus Type $A$ in a current outbreak of respiratory disease. J. A. M. A., 1944, 124, 93.

54. Stuart-Harris, C. H., Glover, R. E., and Mills, H. C., Influenza in Britain, 1942-43. Lancet, 1943, 2, 790.

55. Burnet, F. M., Upper respiratory tract infection. M. J. Australia, 1943, 2, 393.

56. Hare, R., Hamilton, J., and Feasby, W. R., Influenza and similar respiratory infections in a military camp over a period of three years. Canad. J. Pub. Health, 1943, 34, 453.

57. Francis, T., Salk, J. E., and Brace, W. M., The protective effect of vaccination against epidemic influenza B. J. A. M. A., 1946, 131, 275.

Due to excessive inventory, the Journal is offering

a limited number of sets of

Vols. 1 through 11 , complete, unbound, for $\$ 25.00$

(original price $\$ 80.50$ )

There is a limited supply of

the July 1944 issue (Vol. 23, No. 4),

"Chemical, Clinical, and Immunological Studies on the Products of Human

Plasma Fractionation,"

for which there have been many requests.

No additional copies will be available when these are exhausted.

Send orders to: The Business Office

Journal of Clinical Investigation

Cincinnati 29, Ohio

Checks payable to: Journal of Clinical Investigation 